\title{
The Different Types of Words Meaning in Minangkabau Proverbs: A Stylistics Approach
}

\author{
Syamsul Bahri \\ Universitas Negeri Medan, Medan, Indonesia \\ syamsul.bahri0401@gmail.com
}

\begin{abstract}
The objective of this study is to find out the description of several different types of words meaning in Minangkabau Proverbs based on a stylistic approach. This research uses descriptive qualitative method in which the description and interpretation on the real fact or object of the research done by using Minangkabau proverbs recorded from about 8 respondents of Minangkabau Natives. The library study is also done to find several sources focused on stylistic devices based on different types of word meaning in Minangkabau proverbs. This research uses the theory from (Lethsalu, Liiv, \& Mut, 1973). There are two types of stylistic devices, the first types of stylistic devices based on the interaction of lexical and contextual meaning consist of metaphor, metonymy, antonomasia, and irony.The second types of stylistic devices based on different types of word meaning consist of epithet, oxymoron, hyperbole, and meiosis. The findings show that there are several types of word meaning in Minangkabau Proverbs, namely Metaphor 68\%, Metonymy 6\%, Irony 8\%, Epithet 2\%, Hyperbole 6\%, and Zeugma 10\%. The dominant types of word meaning in Minangkabau Proverbs is Metaphor. It shows that people in Minangkabau always use decorated language that uses nature as its object, to show the nature, characteristics or condition of something. Minangkabau people learn about life from nature, the process of something become something better.
\end{abstract}

Keywords

Minangkabau proverbs;

stylistic devices; word meanin

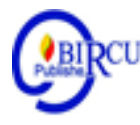

\section{Introduction}

Language is the ability possessed by humans to communicate with other humans using signs, such as words and movements. Scientific studies of language are called linguistics. It is estimated of the number of languages in the world vary between $6,000-7,000$. Because of its diverse types too, language has become an important means of connecting between human beings. Therefore, language can be said to be mandatory and important in terms of communication.

According to Kazeem (2020) Language is an integral part of culture, a reflection of many features of a given culture. Thus, like culture itself, language is a learned behaviour, which can be enhanced through direct or indirect contact.

As a dynamic element, language is always analyzed and studied with various approaches, among others through the meaning approach, while semantics is a component of language that cannot be released in linguistic speech. Without discussing the meaning, the discussion of linguistics has not been considered complete because the act of language is actually nothing but trying to convey the meanings. Speeches that are meaningless have no meaning at all (Parera, 2004: 17). Giving new meaning to what has been experienced or will be experienced in a way that is more than habitual, may make us realize that this is what the poet or novelist is meant to be in certain parts of which we have not yet fully understood (Srinarwati, 2018). Meaning is denotation, while meaning is connotation. Sometimes 
"meaning" is in harmony with "meaning" and sometimes not in harmony. If the meaning of something is the same as the meaning of something, then the meaning is called the Meaning of the Barrel (Explicit Meaning). If the meaning is not in harmony with the "meaning", then something is called having the meaning of the content (Implicit Meaning) or the Meaning of Prevalent (Necessary Meaning).

Meaning is the relationship between form and reference. In general linguistics assumed that must have a list of all the words in the language. So as a language observer must be able to interpret the words correctly in accordance with the context of each sentence. The way of writing an utterance in the language can create the varieties of language and values of art. The style of particular option used by person and social group in their use of language could give a specific stylistic in the use of language. Stylistic is applied to restate the impressionism and subjectively of standard language with a scientific objective analysis of literary text. It can state different taste of thought in writing and various expression of a text. stylistic applies linguistic features, norms and way of expression. It also has the characteristics of particular verbal in text.

In order to finish the study, the researcher used five articles from previous studies to help analyzing the data. The articles are (1) The Use of Minangkabau Proverbs of Contrast Meanings by Minangkabau Society in Medan written by Meisuri and Syamsul Bahri, (2) Minangkabau Proverbs: Values and Functions written by Roswati Silalahi and Ely Hayati Nasution, (3) Minangkabau Proverb: Stimulating High School Students' Critical Thinking and Spatial Thinking written by Silvia Marni, Muhammad Aliman, Emil Septia, and Ninit Alfianika, (4) Proverbs in Martin Amis's London Fields written by Maja Gwóźdź, and (5) Proverbs as artistic miniatures: A stylistic approach written by Jeong O. Park and Ioan Milica.

\section{Review of Literature}

\subsection{Stylistic Devices}

Stylistic devices based on different types of word meaning is a part of lexicophraseological stylistic devices. stylistic devices based on different types of word meaning has three types of word meaning: 1) stylistic devices based on the interaction of lexical and contextual meaning, 2) stylistic devices based on the interrelation of denotation and emotional meaning, and 3) stylistic devices based on interaction of principal and secondary (including figurative) meaning. (Lethsalu, Liiv, \& Mut, 1973).

a. The first types of stylistics devices based on the interaction of lexical and contextual meaning consist of metaphor, metonymy, antonomasia, and irony.

1. Metaphor (Gr. Meta 'change' and phor 'bear') is replace a word with another word which draws a comparison based on similarity of the meaning between two different things. The function of metaphor is to denoting an object and give some expressive characteristics. Thus a metaphor can be considered as a disguised comparison, a foolish person, for example, is referred to as an ass, a spiteful woman may be called a cat, etc.

2. Metonymy (Gr. Metonymy 'changing of name') is a transfer of meaning based upon the association of contiguity. It means that metonymy is a figure of speech which draws a thing with other thing which is a unity of a word itself. The use of metonymy is influenced by culture which means not all words used can be universally understood. For instance, mini 4D changed with Tamiya, mineral water changed to be Aqua, Cigarette changed to 
3. be Gudang Garam (one of the types of cigarette), etc. There is another figure of speech that related to metonymy and often included under it, Synecdoche. Synecdoche (Gr. Synecdoche 'receiving together), a figure of speech by which a part is used for a whole or a whole for a part, the singular for the plural or the plural for the singular, the special for the general or vice versa.

4. Antonomasia has a close relationship with metaphors and metonymy. Similar to metonymy, antonomasia uses right name to express a general idea or the nickname change to the right name. The difference with metonymy, antonomasia can be recognized in general without having to know the culture or background of a country or place. The use of this antonomasia is replaced by a common name or general thing that all corners of the world understand (universally understood) e.g. When it becomes necessary to kick John Bull out of America, Mr. Washington stepped forward, and performed that job with satisfaction; (Thackeray, BS) (John Bull = the English people or the typical Englishman); It satisfied the police and Mrs. Grundy; (Galsworthy, B) (Mrs. Grundy = society in regard to its censorship of personal conduct). Names taken from ancient history, mythology or the Bible are also frequent, e.g. With only a stepmother - closely related to Jezebel; (Galsworthy, L) (Jezebel = the wife of Ahab, king of Israel, notorious for her conduct); Tripping airily into its office, she laid a scrap of paper before a lovely Hebe who was typing there; (Coppard, FF) (Hebe = in Greek mythology the goddess of youth and spring)

5. Irony (Gr. Eironeia 'simulated') is a figure of speech in which the literal meaning of the lexical unit is the opposite of the truth. So, the utterance is different from the intended. Irony draws a negative situation with a positive response or reaction, e.g. when a man laughs when others are in bad luck, or when someone laughs at himself when having bad luck, and the butter is as soft as a slab of marble. The word "as soft as" is the irony, positive response to describe the bad butter.

b. Stylistics devices based on the interrelation of denotation and emotional meaning as the second types of stylistics devices based on different types of word meaning consist of epithet, oxymoron, hyperbole, and meiosis

1. Epithet (Gr. epitheton 'addition') is a figure of speech which shows a permanent or temporary quality of person, thing, idea or phenomenon in subjective perception as the point of view in characterizing it. An epithet has always an emotional meaning which accompany the denotation meaning or it may exist independently or connotation. Epithets established in the language are often based on a permanent feature or a notion. Wordcombinations like 'true love *. * green wood*, * merry maid', 'lady gay', 'merry old England 'bonny ship'. etc., and frequent in popular ballads or their imitations, e.g.

Since my true love has forsaken me,

Marti'mas wind, when wilt thou blaw

And shake the green leaves aff the tree?

(WalyWaly)

2. Oxymoron (Gr. Oxys 'sharp' + moron 'stupid') is a figure of speech that combines the use of an epithet or attributive phrases that is contradictory with one another. In short, oxymoron is a contradiction in terms. An oxymoron is used to provide figurative characterization of ideas and reveal the intricate nature of the mind. And serves to show the permanent or temporary features of an idea e.g. it was with an almost cruel joy and perhaps in nearly every joy, as certainly in every pleasure cruelty has its place - that he used to read the latter part of the book; (Wilde, PDG), with a purely emotional meaning, such as 'it's awfully nice of you', 'I'm terribly glad', etc. Sometimes it is not the attribute that changes its meaning in an oxymoron, but the head-noun, e.g. In Norman's brain there was a silent scream of triumph; (Steinbeck, WB). 
3. Hyperbole (Gr. Hyper 'beyond' + balle in 'to throw') is a redundant transfer of meaning that is not meant to be taken literally. It means, hyperbole is used to strengthen an impression by exaggerating. The purpose of hyperbole is to show the expression of the speaker's emotional attitude towards the thing being discussed. Hyperbole level is based on the interaction of emotional meaning and the meaning of a word. However, not every exaggeration can be considered a stylistics device. The results of hyperbole that exaggerate often make sentences read or sound funny or do not need to be taken seriously, "big deal", or so on. It causes hyperbole as rhetorical devices, e.g. "Haven't seen you for ages!" (Galsworthy, Ch) "I'm dying to see what my second one is, ${ }^{*}$ ' cried Gudrun, (Lawrence, WL); (Cronin, C) My mother was shocked to the marrow of her bones by the thought that I should become for years what seemed to her nothing but a manual worker. Hyperbole is of very common occurrence in poetry, e.g.

Dissolve, thick cloud, and rain; that I say.

The gods themselves do weep!

(Shakespeare, AC)

4. Meiosis (Gr. meiõsis (meioõ 'lessen' f. meion 'less')) or understatement is a statement which is not representing with completeness all the aspects of the case. In other words, Meiosis is a figure of speech that minimizes the importance of something through euphemism. Meiosis is an attempt to underestimate the significance or size of an unpleasant thing, although not all examples of meiosis refer to something negative, e.g. imperial fiddlestick!" said the King, rubbing his nose, which had been hurt by the fall. He had a right to be a little annoyed with the Queen, for he was covered with ashes from head to foot; (Carroll, TLG) They would not remember the simple rules their friends had taught them that ... a red- hot poker will burn you if you hold it too Ions; and that if you cut your finger very deeply with a knife, it usually bleeds; and she had never forgotten that if you drink too ä much from a bottle marked 'poison', it is almost certain to disagree with you sooner or later. (Carroll, AAWL)

c. And based on different types of meaning, stylistic devices based on interaction of principal and secondary (including figurative) meaning is the last types which has zeugma as the one and only of the body

1. Zeugma (Gr. zeugnunai 'to yoke, join') is a figure of speech based on the interaction of different denotation meanings. Zeugma uses the illogical word and ungrammatical in the structure of the second syntactic construction. The effect is rise the complex sentence (the sentence feels confused). For instance, I need to tell you, my grandmother is a friendly and angry person.

\subsection{Proverb}

Proverb is a word that use to express an advice or proven truth. It's Because most proverbs have their origins in oral tradition. They are generally worded in such a way as to be remembered easily and tend to change little from generation to generation. Generally, Proverb has figurative language such as metaphor and formulaic language. Some proverbs exist in more than one language because people borrow them from languages and cultures similar to theirs. According to Mieder. 1993, a proverb is a short, generally known sentence of the folk which has wisdom, truth, morals, and traditional views in a metaphorical, fixed, and able to memorize form and which is handed down from generation to generation. Proverb generally use in several occasion, in conversation, in literary works, in drama or movie, in music, in visual form.

For example: 
1. A bad workman always blames his tools.(This proverb means that someone who blames the quality of their tools or other external factors when they do a task badly)

2. Absence makes the heart grow fonder.(We will feel much love of someone when she is not with us)

3. A cat has nine lives.(Cat can live longer in worst condition)

4. A drowning man will clutch at a straw. (Someone will take an action if he is in worst situation as a prove that he can do it)

5. Adversity and loss make a man wise. (We can get a lesson of wisdom in a difficult situation rather than in a wealthy condition. )

\subsection{Proverbs in Minangkabau}

Indonesia is a vast country with various cultures that goes from east to west, Sabang to Merauke with great differences from one to another, each with their own uniqueness. One example for the culture is Minangkabau, centralized in West Sumatra province, it also spread all over Indonesia and known for their proverbs.

Minangkabau proverbs take important roles in various cultures like traditional ceremony such as marriage, birth, death, etc , through 6 field of life, social culture, economy, social politics, law, defense, and religion. Through the proverbs, meaningful moral values were represented to the people to build their way of thinking based on the local wisdom they have. These down below are the examples of proverb that represent the local wisdom of Minangkabau.

1. Bak gulagak gulai kincuang, bak konjak galangan tingga. (Acts as knows everything, but hollow inside)

2. Elok rarak di hari paneh, elok lenggang di nan data. (Those who are rich can do everything at anytime)

3. Aia urang disauak, rantiang urang dipatah, adiak urang dituruik (when in Rome, do as Romans)

4. Elok diambiak jo etongan, buruak dibuang jo mupakaik (Making decision through voting is good, the beter is agreement)

5. Indak bingkudu tak bagatah, antah kok birah jo kaladi. Indak penghulu nan ta gawa, antah kok Allah dengan nabi. (Humans are not perfect, Allah and the Prophet are).

\section{Research Methods}

This research was conducted by utilizing descriptive qualitative method in which the description and interpretation on the real fact or object of the research done by using Minangkabau proverbs recorded from about 8 respondents of Minangkabau Natives. The library study is also done to find several sources focused on stylistic devices based on different types of word meaning in Minangkabau proverbs.

\section{Discussion}

\subsection{Research Result}

a. Metaphor

1. Aia diminum raso duri, nasi dimakan raso sakam

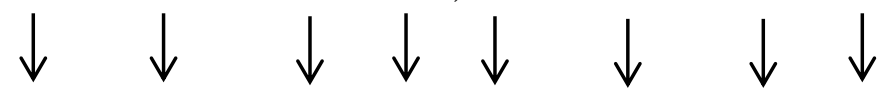

water drunk tase torn rice eaten taste bitter

(Someone who has an inner and painful suffer) 
This proverb has a metaphorical style of writing in which there is the use of "duri" and "sakam" means pain and bitter. The utterance of proverb shows someone who is really in a suffer condition even while drinking is not enjoyable anymore because the water is like torn and gives a taste of bitter. Otherwise, suffer is also gained while eating the rice and is hard to shallow. The pleasure of a meal and drink is lost, the existing pain and bitter is only tasted in his life caused probably by a certain problem or disease. The use of diction "duri "and" sakam" states a meaning of metaphor in Minangkabau proverbs.

2. Harilah paneh, lupo kacang jo kuliknyo

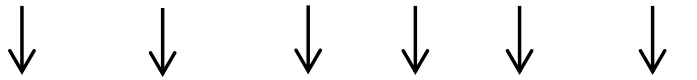

today hot forget bean with its'cover

(Someone who forgot a favor of someone else after he got a success)

The style of writing in this proverb concerns in metaphorical meaning in which the phrases "lupo kacang akan kulik nyo" states the meaning for someone who is selfish and after getting a success, someone who has ever assisted is already forgotten. The kindness of someone is not appreciated anymore and it is really discarded. He does not realize who he was and forgets what condition he had before getting a success and omit all the kindness of someone else` favour to him. Of course, the phrase " lupo kacang akan kulik nyo" enriches the utterance of Metaphor in Minangkabau proverbs.

3. Musang babulu ayam musuah dalam salimuik

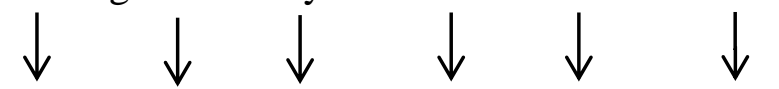

weasel furry chicken enemy in blanket

(someone who pretends to be nice in front of us but indeed we are beaten from back).

The use of " ayam" (chicken) in this proverb creating the sentence having the sense of metaphorical meaning in which it has a purpose to states someone who pretends tobe nice friend for us but indeed he is a bad one. Trying to hide a bad conduct inf ront of us but he did something bad at back. In Indonesian, it is similar with the proverb "musuh dalam selimut" ( enemy in the blanket ), a great pretender tobe nice but trying to ruin us possibly caused by jealous, envy or a bad conduct. This utterance already adds the meaning of metaphorical style of writing in Minangkabau proverbs.

b. Metonymy

1. Kalau menimbang samo barek, jikok maukuah samo panjang

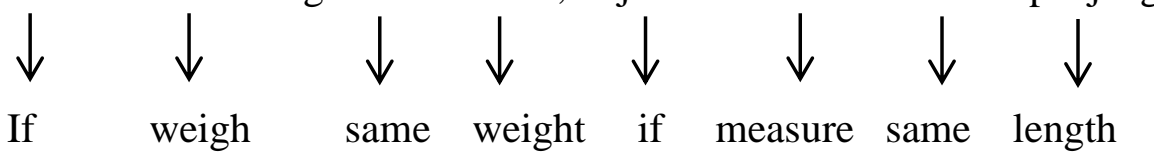

This proverb does not concern about the word "weight and length", however, it asks the people to be fair in this life, especially a judge must be fair in taking a decision in the court for the sake of justice for the people. This proverb is considered as a wise word to inform Minangkabau people to be fair in every situation of activities and hold a justice in this life. It can be stated in the words " manimbang samo barek" that means doing something in the same responsibility on the same justice for several things. It does not cling only for one side but it must be fair for everyone, such as a judge must stand a justice in giving punishment for someone. 
2. Salah ka tuhan mintak tobat, salah ka manusia mintak maaf.

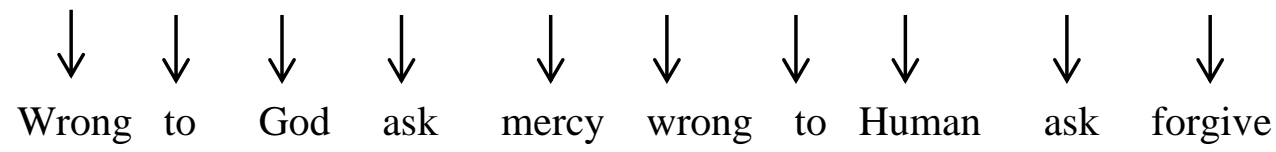

The proverb uses the word "Tuhan" and "manusia" means God and human as style of writing which is metonymy. This proverb doesn't concern to "God" and "human", but it talking about the sin level done by human. The word "Tuhan" and "manusia" reveal or the implicit meaning of level of sin done by human, whether high or low and small or big. So, the word "Tuhan" (God) mean the big or high level of the sin and "manusia" (human) means the low or small level of the sin. The uses of Minangkabau proverb to make the word look like stylish one.

3. Tapuang jan terserak, rambuik jan sampai putuih

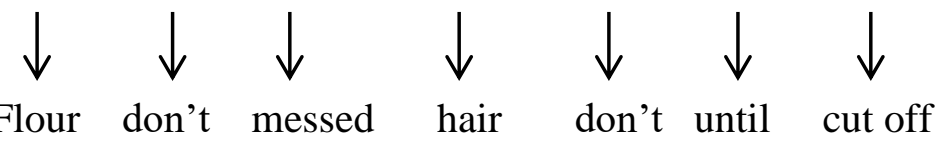

The proverb doesn't concern to the "flour and hair". It doesn't show the meaning of the word directly. There is another meaning contained of the proverb. This Minangkabau proverb shows one of the use of stylistic devices, metonymy. The word "tapuang" means conflict and the word "hair" in Minangkabau proverb means relationship. This proverb use to express the feeling and relationship should have by involved people to the conflict. The proverb asks the people who involved to keep the relation. Even the conflict has done, the relationship between the involved have to keep it.

c. Irony

1. Mambaka tapi tak barapi

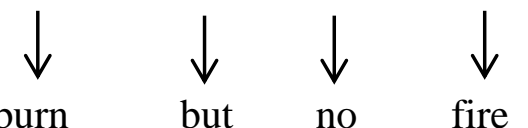

burn but no fire

(A person who does not truly love his lover)

This Minangkabau proverb has a ironical meaning for people who like to play fire with the word love. People who like to spit the word of love and affection but whose actions show they don't really love their lovers. The words 'mambaka' means 'burn' and ' tak barapi' means' no fire' as the contract one showing irony for one condition in which someone who just says love as utterance of his mouth only but his conduct proves that he does not really love his lover.

2. Mangabek indak batali

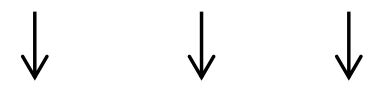

tied no having a rope

(Someone who does something but he is not responsible)

This Minangkabau proverb has the meaning of sarcasm for someone who has done something or work but is not responsible for the work. This proverb describes someone who did a kind of work but he is not responsible for it until finished. The words mangabek 'tied' 
and indak batali ' having no rope` are contrast and have ironical meaning to satirize someone who is not responsible for his job. Firstly ,He shows to the others that he did something for a certain work, but indeed he is not responsible for finishing his work well.

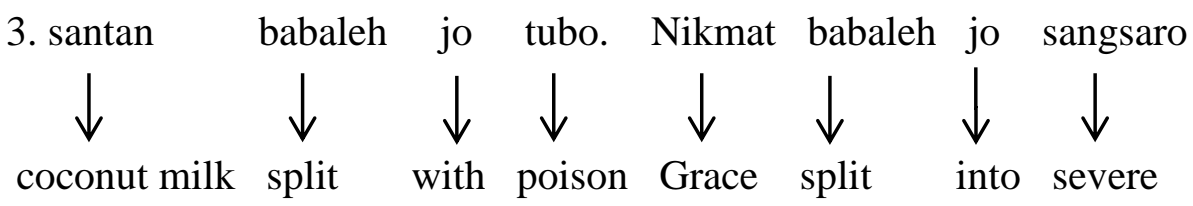

This proverb explains that someone responses the kindness of someone else with the bad thing. It has an ironical meaning showed by the words nikmat 'pleasure' and sangsaro 'suffer' both are contrast words 'pleasure' and suffer are done in one conduct someone who forget the kindness of someoneelse and does the bad response to him. It is like Indonesian proverb 'Air susu dibalas dengan air tuba'. The kindness is resiprocally response by bad conduct.

d. Epithet

1. Hujan batu di kampuang awak, hujan ameh di kampuang urang.

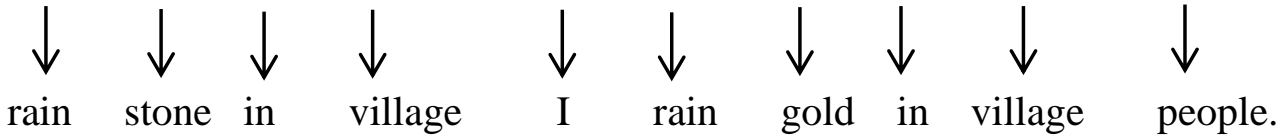

This proverb has an epithet style of writing showed by the words "hujan batu and hujan ameh". The use of "hujan batu" and "hujan ameh" means stone and gold rains. The utterances use by the author to describe the situation and condition which is happening to someone. The words "stone rain" means disaster and "gold rain" means fortune. The proverb above says that disaster happen to someone's village and the fortune come to others village which is not involve by someone who receive the disaster. In other words, someone tells the condition of her/his village and compare to other village.

e. Hyperbole

1. Satitiek jadikan lawik, sakapa jadikan gunuang

a spot became sea handful became mountain

The use of words 'Satitiek jadikan lawik, sakapa jadikan gunuang' showing an hyperbole to show the value of optimism in which a little thing is done in exploring the knowledge and science bit by bit getting skill full. The process of effort from the small one, and it is done gradually bit by bit, finally it will get a satisfied final is a big person full of skill and knowledge.

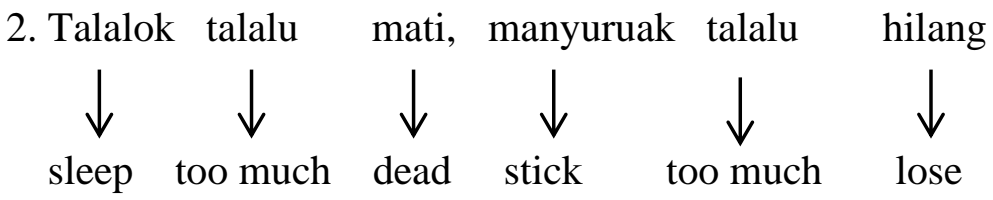

This proverb describes a person who ignores the surroundings in society, has a high intelligent on his mind but he does not want to be associated with many people. He is usually isolated by himself from the society and does not want to show his responsibility for 
surroundings. His cleverness is just for himself and he does not do its`implementation among the society.

3. Putiah mato mananti nan tak kunjuang tibo

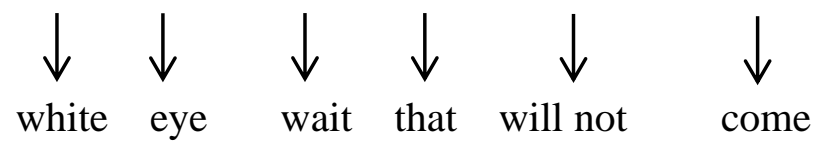

This Minangkabau proverb has s sense of hyperbole meaning in the style of writing. The use of words "putiah mato" shows hyperbole in one condition of waiting for someone. It states a sense of one boring condition waiting for someone who does not come. It takes a long time to wait for but someone whom waiting for never comes. This utterance is really exaggerated to express a boring feeling in waiting for someone whom never come by describing his eyes become white eyes "putiah mato".

\section{f. Zuegma}

1. Dalam aie bulie diajuak, dalam hati siapo tahu

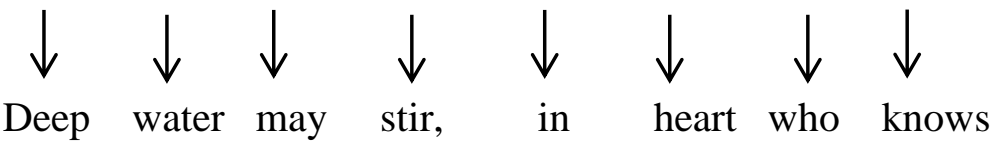

This proverb has a zeugma style of writing. Zeugma happens when the sentence is illogical and ungrammatical order. In "Dalam aie bulie diajuk, dalam hati siapo tahu" applies to two things in different sense, the word "air and hati" which means water and heart. Water and heart are the nouns. The nouns are illogical and ungrammatical order because the nouns have different ideas which are brought together in a sentence.

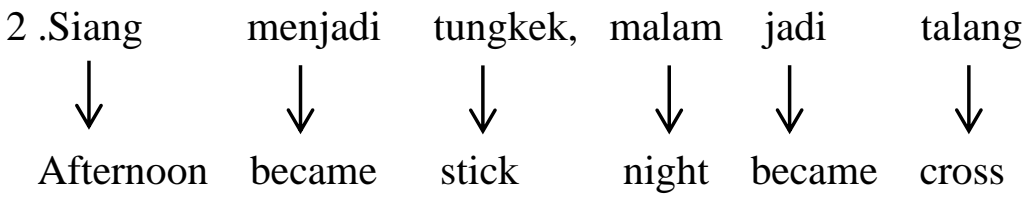

This kind of Minangkabau proverb is belongs to zeugma. In other words, the proverb has a zeugma as one of stylistic devices. The sentence "when afternoon became a stick and night became a cannelure" shows the incoherence in the sentence. The point is the use of "tungkek and talang" means stick and cannelure. How a thing can be a stick in the afternoon and become a cannelure in the night? The question just shows how illogical the sentence is and it is an absurd thing.

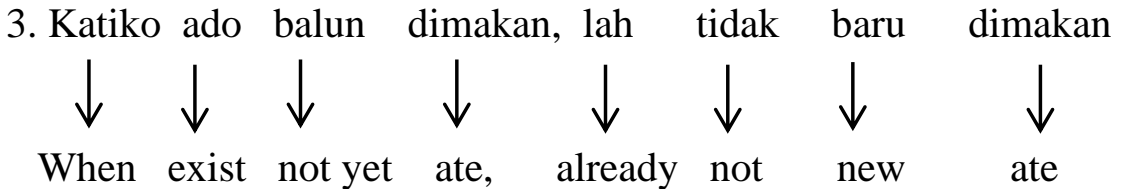

The proverb above belongs to one of stylistic devices which is zeugma. The sentence of "katiko ado balun dimakan, lah tidak baru dimakan" means when exist doesn't eat yet, when in front of the eyes there is no interest to eat it. From the meaning, there is incoherence in the sentence which means the utterance is illogical. The illogical is "lah tidak baru dimakan". 
Why have to looking for something that doesn't exist while when the thing is in front of the eyes, there is no interest to eat it. It looks like someone doing an absurd thing and useless.

\section{Conclusion}

After having the calculated data of this research, the result can be shown in this following diagram

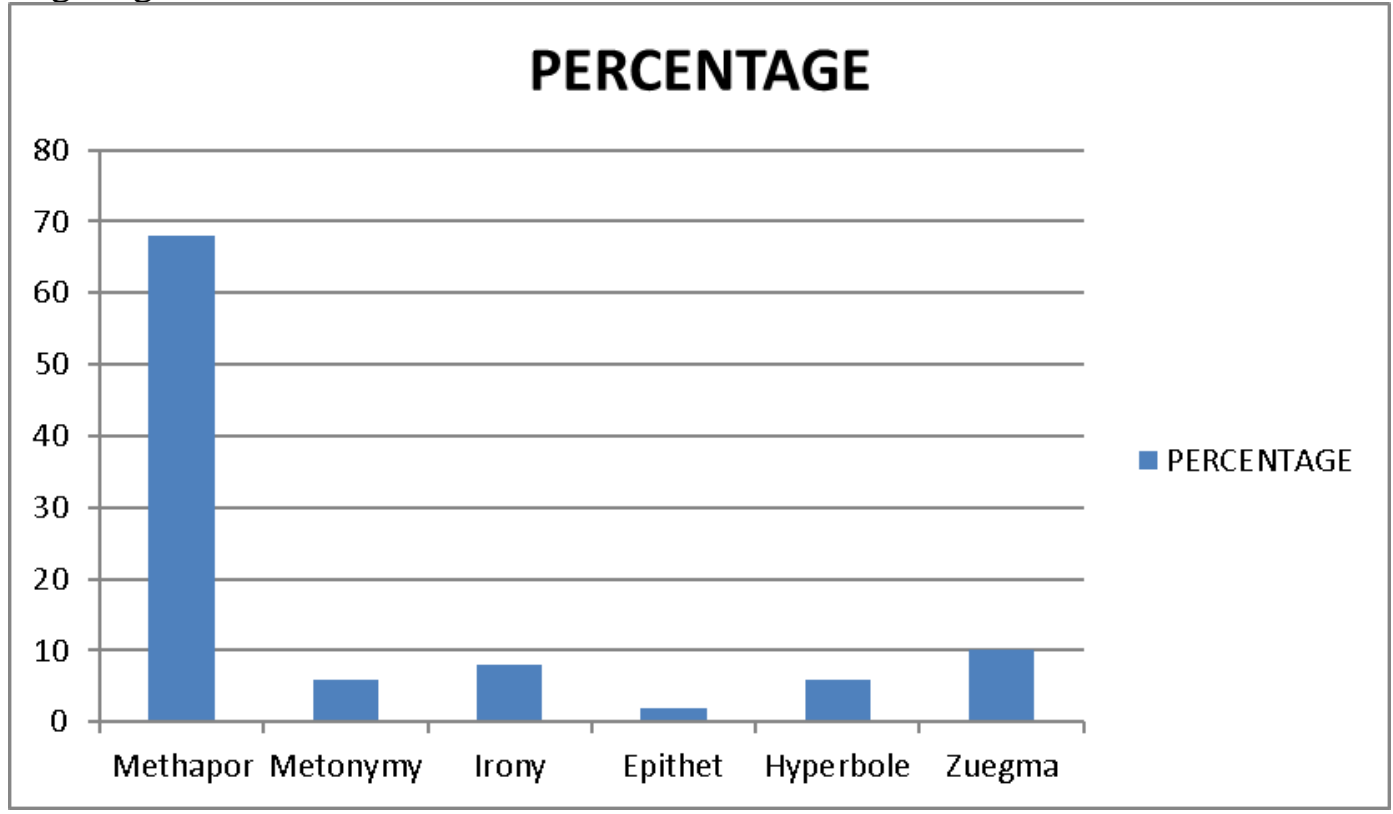

From the results of this study, there are several different types of word meaning in Minangkabau Proverbs found namely Metaphor 68\%, Metonymy 6\%, Irony 8\%, Epithet $2 \%$, Hyperbole $6 \%$, and Zuegma $10 \%$. However, the use of metaphors in the Minangkabau proverb was the most. This relates to the habits of the Minangkabau people who always use decorated language that uses nature as its object. The elements or objects related to nature are always used in the Minangkabau proverb to indicate the nature, characteristics or conditions of something. This is also closely related to the philosophical principle of the Minangkabau people that "Alam takambang manjadi guru." From nature, Minangkabau people learn about life, the process of something becoming something better, the function of how life really is and the usefulness of something to the Minangkabau community and the interaction of people and nature in the Minangkabau community. The use of Minangkabau proverbs of metaphors, this is also influenced by the customs of the Minangkabau people who must uphold good attitudes and treatment called Attitude in communication. Because of Attitude in socializing and communicating is very important to keep up harmonious relationships each other. Attitude in communication that always smooths the language used in a way of decorating, so that many Minangkabau proverbs have a figurative connotation of something. This is also to smooth the language itself so that others are respectful and the language is beautiful and pleasant to hear that can give good interaction between fellows of Minangkabau people in order to let the harmony occur in communication. 


\section{References}

Kazeem, A. S. and Suleiman, M. I. (2020). Prospects and Problems of Language Policy to Indigenous Languages in Nigeria. Britain International of Linguistics, Arts and Education Journal. 2(1): 330-337.

Meisuri \& Syamsul Bahri. (2019). The Use of Minangkabau Proverbs of Contrast Meanings by Minangkabau Society in Medan. Budapest International Research and Critics in Linguistics and Education (BirLE) Journal. Vol 2 (4); 79-88.

Park, O Jeong \& Ioan Milica. (2016). Proverbs as artistic miniatures: A stylistic approach. Researchgate. https://www.researchgate.net/publication/316432801

Gwozdz, Maja. (2016). Proverbs in Martin Amis's London Fields: A Stylistic Devices.

Silalahi, Roswita \& Ely Hayati.(2017). Minangkabau Proverbs: Values and Functions. Atlantis Press. Vol 141. https://www.researchgate.net/publication/323181944.

Srinarwati, D.R. (2018). The Disclosure of Life Experience and Its Expression in Cultural Studies Perspective. Budapest International Research and Critics Institute (BIRCIJournal) : Humanities and Social Sciences. 1(2); 125-141.

Marni, Silvia et all. (2020). Minangkabau Proverb: Stimulating High School Students' Critical Thinking and Spatial Thinking. Researchgate. https://www.researchgate.net/publication/338359261

Letsalu et all.(1973). An Introduction to English Stylistics.Estonia : Tartu 